\title{
Moult of the emperor penguin: travel, location, and habitat selection
}

\author{
G. L. Kooyman ${ }^{1, *}$, E. C. Hunke ${ }^{2}$, S. F. Ackley ${ }^{3}$, R. P. van Dam ${ }^{1}$, G. Robertson ${ }^{4}$ \\ ${ }^{1}$ Scholander Hall, 0204, Scripps Institution of Oceanography, La Jolla, California 92093, USA \\ ${ }^{2}$ MS-B216, Los Alamos National Laboratory, Los Alamos, New Mexico 87545, USA \\ ${ }^{3}$ Cold Regions Research and Engineering Laboratory 72 Lyme Rd., Hanover, New Hampshire 03755, USA \\ ${ }^{4}$ Australian Antarctic Division, Channel Highway, Kingston 7050, Tasmania, Australia
}

\begin{abstract}
All penguins except emperors Aptenodytes forsteri and Adelies Pygoscelis adeliae moult on land, usually near the breeding colonies. These 2 Antarctic species typically moult somewhere in the pack-ice. Emperor penguins begin their moult in early summer when the pack-ice cover of the Antarctic Ocean is receding. The origin of the few moulting birds seen by observers on passing ships is unknown, and the locations are often far from any known colonies. We attached satellite transmitters to 12 breeding adult $A$. forsteri from western Ross Sea colonies before they departed the colony for the last time before moulting. In addition, we surveyed some remote areas of the Weddell Sea north and east of some large colonies that are located along the southern and western borders of this sea. The tracked birds moved at a rate of nearly $50 \mathrm{~km} \mathrm{~d}^{-1}$ for more than $1000 \mathrm{~km}$ over $30 \mathrm{~d}$ to reach areas of perennially consistent pack-ice. Almost all birds traveled to the eastern Ross Sea and western Amundsen Sea. Sea-ice conditions were observed directly in the Weddell Sea from ship and helicopter. Most floes selected for moulting were ridged, and usually $>100 \mathrm{~m}^{2}$. From these observations we predict where the most likely moult refuges are for emperor penguins from other colonies around the Antarctic continent.
\end{abstract}

KEY WORDS: Satellite transmitter $\cdot$ Antarctica $\cdot$ Ross Sea $\cdot$ Weddell Sea $\cdot$ Amundsen Sea $\cdot$ Pack-ice

\section{INTRODUCTION}

Feathers set birds apart from all other groups of vertebrates. They make up $\sim 5$ to $15 \%$ of the body mass (Voitkevich 1966, Welty 1975), and they form an important insulating layer against cold water (Kooyman et al. 1976). Wear and tear on feathers requires that they be replaced frequently throughout the life of the bird. The complexity and variability of life styles among different species result in different modes of replacement. Most flying birds replace feathers gradually over many weeks. Some grebes (Podicipedidae), geese (Anatidae) and loons (Gaviidae) replace the feathers rapidly, and the abrupt feather loss leaves

*E-mail: gkooyman@ucsd.edu them flightless for several weeks (Welty 1975). This rapid moult is also typical of penguins, and during the approximately 2 to 4 wk moulting period, depending on species, they must find a stable, protected location where they can remain dry (Adams \& Brown 1990).

Unlike all other penguin species, emperor and Adelie penguins do not usually moult on land or near their breeding colonies. Emperor penguins do not have any option. All colonies, with 2 exceptions, are located on annual fast-ice. At the time of year when the breeding birds moult, the sea-ice at the colonies has disintegrated and disappeared, or is likely to do so. These summer conditions of depleted sea-ice, when the pack-ice coverage of the Southern Ocean in February is $4 \times 10^{6} \mathrm{~km}^{2},<25 \%$ of the winter maximum extent of $19 \times 10^{6} \mathrm{~km}^{2}$ (Gloersen et al. 1992), place the birds at some risk. Because of the extensive loss of ice habitat, 
which continues to decline during the moult, the loss of mobility, the long fast, and a high metabolic rate while moulting, the period of moult may be the most critical time of year for adult emperor penguins, and therefore, potentially the time of highest mortality.

To accomplish the moult successfully, the birds must find an ice platform that will remain secure for a month. Emperor penguins are rarely seen on land, which suggests that for some reason they are reluctant to come ashore. One of us (Robertson pers. obs.) noted about 60 birds moulting in front of the Taylor Glacier and 400 to 600 moulting on fast-ice among scattered icebergs near the Auster colony. These may be the largest concentrations of moulting emperor penguins ever seen; yet these groups are a small percentage of the $\sim 5800$ breeders using the Taylor Glacier site, and the $\sim 22000$ breeders from the Auster colony.

Even more extreme is the situation in the Ross Sea colonies. About 100000 birds breed at the 6 colonies along the western shores and islands of the Ross Sea. Only a handful of birds have been seen moulting. For example, more than 50000 birds breed at the Cape Washington colony, but during December and January no more than a dozen birds moult on the adjacent fastice of Terra Nova Bay.

Our objectives were to determine: (1) where breeding emperor penguins from 4 Ross Sea colonies moult; (2) if there is any consistency in the moult location among the birds; (3) the departure time from the colony to the moult area ${ }_{i}(4)$ the travel speed and distance; (5) pack-ice distribution at the moult site; (6) by direct observations, some characteristics of a moult site.

\section{METHODS}

Tracking. Satellite transmitters were glued to feathers of the lower back of 12 emperor penguins Aptenodytes forsteri with Devcon 5 min epoxy. They were further secured with nylon cable ties. The 2 types of transmitters used were Toyocom T2038 (Toyo Communication Equipment Co., Koza-gun, Kanagawa Prefecture, Japan), aluminum tube mass $=195 \mathrm{~g}$, dimensions $=3.5 \mathrm{~cm}$ diam $\times 16 \mathrm{~cm}$ long, and Telonics ST- 6 (Telemetry Electronics Consultants, Mesa, Arizona, USA), which we imbedded in plastic. The mass of the latter deployed transmitter was $450 \mathrm{~g}$, dimensions = $2.5 \mathrm{~cm}$ thick $\times 5.5 \mathrm{~cm}$ wide $\times 25 \mathrm{~cm}$ long. Both transmitters had antenna lengths of $15.7 \mathrm{~cm}$. The antenna projected out at the back in line with the long axis of the transmitter, and we applied a tapered nose to both types of transmitters to reduce drag. Characteristics of the birds and the type of transmitter are given in Table 1.

Argos, a satellite-based location system, provided the fixes. Since the birds most probably rested out of water daily, we used only Classes 1 to 3 quality locations, $1 \mathrm{~d}^{-1}$. Transmissions were programmed for a duty

Table 1. Aptenodytes forsteri. Travel properties after departure from colony to moulting site. Numbers in parentheses for maximum distance $=$ total distances summed for each location; number in parentheses for speed = range and number of locations; $-=$ no data; letters in 'Bird code' indicate colony of origin (see text)

\begin{tabular}{|c|c|c|c|c|c|c|c|}
\hline $\begin{array}{l}\text { Bird } \\
\text { code }\end{array}$ & $\begin{array}{l}\text { Body mass } \\
\quad(\mathrm{kg})\end{array}$ & $\begin{array}{l}\text { Departure } \\
\text { date } \\
(\mathrm{mo} / \mathrm{d} / \mathrm{yr})\end{array}$ & $\begin{array}{l}\text { Arrival } \\
\text { date } \\
(\mathrm{mo} / \mathrm{d} / \mathrm{yr})\end{array}$ & $\begin{array}{l}\text { Last- } \\
\text { transmission } \\
(\mathrm{mo} / \mathrm{d} / \mathrm{yr})\end{array}$ & $\begin{array}{l}\text { Maximum } \\
\text { distance } \\
(\mathrm{km})\end{array}$ & $\begin{array}{l}\text { Speed enroute } \\
\quad(\mathrm{km} / 24 \mathrm{~h})\end{array}$ & $\begin{array}{l}\text { Moult speed } \\
(\mathrm{km} / 24 \mathrm{~h})\end{array}$ \\
\hline $\mathrm{CC} 66^{\mathrm{a}}$ & 26.8 & - & $12 / 29$ & 01/10/95 & 201 & - & - \\
\hline $\mathrm{CC} 67^{\mathrm{a}}$ & 34.0 & $12 / 11 / 94$ & $12 / 26$ & $01 / 11 / 95$ & 68 & - & - \\
\hline $\mathrm{CZ7} 70$ & 27 & $12 / 06 / 92$ & - & $01 / 05 / 93$ & $1330^{\mathrm{d}}(1280)$ & $42.5(0.9-120,11)$ & - \\
\hline CW66 & - & $12 / 15 / 92$ & $01 / 12 / 93$ & $02 / 04 / 93$ & $1068^{\mathrm{d}}(1290)$ & $43.6(6.6-74,19)$ & $8.9(1.2-22.1,22)$ \\
\hline CW82 & 23.9 & $12 / 11 / 93$ & $01 / 21 / 94$ & $02 / 16 / 94$ & $1120^{\mathrm{d}}(1270)$ & $35.8(3.7-149,18)$ & $8.7(1.3-18.5,22)$ \\
\hline CW87 & 25.7 & $12 / 22 / 93$ & $01 / 22 / 94$ & $02 / 05 / 94$ & $1290^{\mathrm{d}}(1600)$ & $48.8(8.3-123,22)$ & $5.9(.03-17.9,12)$ \\
\hline CW88 & 22.8 & $12 / 22 / 93$ & $01 / 27 / 94$ & $02 / 17 / 94$ & $1291^{\mathrm{d}}(1850)$ & $48.9(1-321,18)$ & $8.8(0.6-34,21)$ \\
\hline CW70 & 24.7 & $12 / 22 / 93$ & $01 / 17 / 94$ & $02 / 14 / 94$ & $1384^{\mathrm{d}}$ & $57.5(0.1-76,6)$ & $9.0(0.4-24.2,26)$ \\
\hline $\mathrm{CI} 91^{\mathrm{b}}$ & 23.9 & $12 / 26 / 92$ & $01 / 06 / 93 ?$ & $01 / 06 / 93$ & $337^{\mathrm{e}}$ & - & - \\
\hline $\mathrm{CI} 21^{\mathrm{b}}$ & 22.1 & $11 / 06 / 93$ & $12 / 18 / 93$ & $12 / 18 / 93$ & $676^{\mathrm{e}}$ & - & - \\
\hline CI69 & 21.6 & $12 / 25 / 93$ & $01 / 14 / 94 ?$ & $01 / 14 / 94$ & $980(1010)$ & $42.1(47-89,3)$ & - \\
\hline CR86 & 22.7 & $11 / 02 / 93$ & $12 / 28 / 93$ & $02 / 24 / 94$ & 906 & - & - \\
\hline CR89 ${ }^{b}$ & 22.7 & $10 / 28 / 93$ & $01 / 31 / 94$ & $02 / 25 / 94$ & $1306(1680)$ & $68.8(0.8-139,11)$ & $0.8(0.06-7.4,23)$ \\
\hline CR90 ${ }^{b}$ & 21.4 & $11 / 30 / 93$ & $01 / 30 / 94$ & $03 / 03 / 94$ & 1434 & $36.2(2.1-151,17)$ & $7.8(0.6-43,36)$ \\
\hline Mean (SD) & $23.8(1.31)^{\mathrm{C}}$ & $\sim 20 \mathrm{Dec}$ & $22 \mathrm{Jan}$ & 12 Feb & 1245 (153) & $47.1(9.94)$ & $7.1(2.78)$ \\
\hline \multicolumn{8}{|c|}{$\begin{array}{l}\text { aBoth transmitters at Cape Colbeck stopped functioning before moult } \\
\text { bNever returned to the colony } \\
{ }^{c} \text { Only birds captured in December } \\
\text { dBirds used for mean values } \\
\text { eTransmitter stopped functioning while enroute to moult }\end{array}$} \\
\hline
\end{tabular}


cycle of $12 \mathrm{~h}$ on in $24 \mathrm{~h}$. This cycle matched the most likely time the birds would be resting on ice floes. According to the Argos 1996 User Manual, the accuracy of Class 1 locations is $<1 \mathrm{~km}$. These daily fixes were used to calculate travel rates. The use of only $1 \mathrm{fix} \mathrm{d}^{-1}$ smoothed the records and gave us the minimum amount of travel.

Duration. We conducted this study over the course of $3 \mathrm{yr}$ (Table 1). In 1992 we deployed 6 transmitters from 3 colonies, Coulman Island (CI), Cape Washington $(\mathrm{CW})$, and Cape Crozier (CZ), with the primary intent of determining foraging distribution in November while the birds were nurturing chicks (see Fig. 2). Three of the transmitters lasted long enough for us to determine moult locations. The most successful was CW66, which was removed from one bird and placed on another bird in December for the express purpose of determining moult location. The following year we deployed transmitters from CW, CI and Cape Roget (CR), and obtained the moult locations for at least 1 bird from each colony. In 1994, 2 transmitters were deployed early in the year from the newly discovered Cape Colbeck colony at the edge of the eastern Ross Sea. These transmitters were also deployed mainly to track the foraging travels of birds nurturing chicks, but they lasted long enough to give a general location for the moult site as well.

Satellite imagery and direct observations. Ice images were obtained from NOAA-9 and 10 satellites. The images were advanced very high resolution radar (AVHRR) and optical line scanner (OLS).

Direct observations were made from the HMS 'Endurance' and the supportive helicopters while on assignment in the Weddell Sea during January and February 1998 for the Ronne Polynya Experiment (Hunke \& Ackley 1998, unpubl.).

\section{RESULTS}

\section{General}

The bird code names, their colony of origin, body mass at the time of capture, and departure date from the Aptenodytes forsteri colony to the moult area are summarized in Table 1. The average mass of birds captured in December just prior to abandoning the chick was $23.8 \mathrm{~kg}$ (1.31 SD). The average date of departure from the colony was 20 December, and the average arrival date at the moult site was 22 January. Over the course of the month the birds spent traveling, the average distance of the most direct path from the
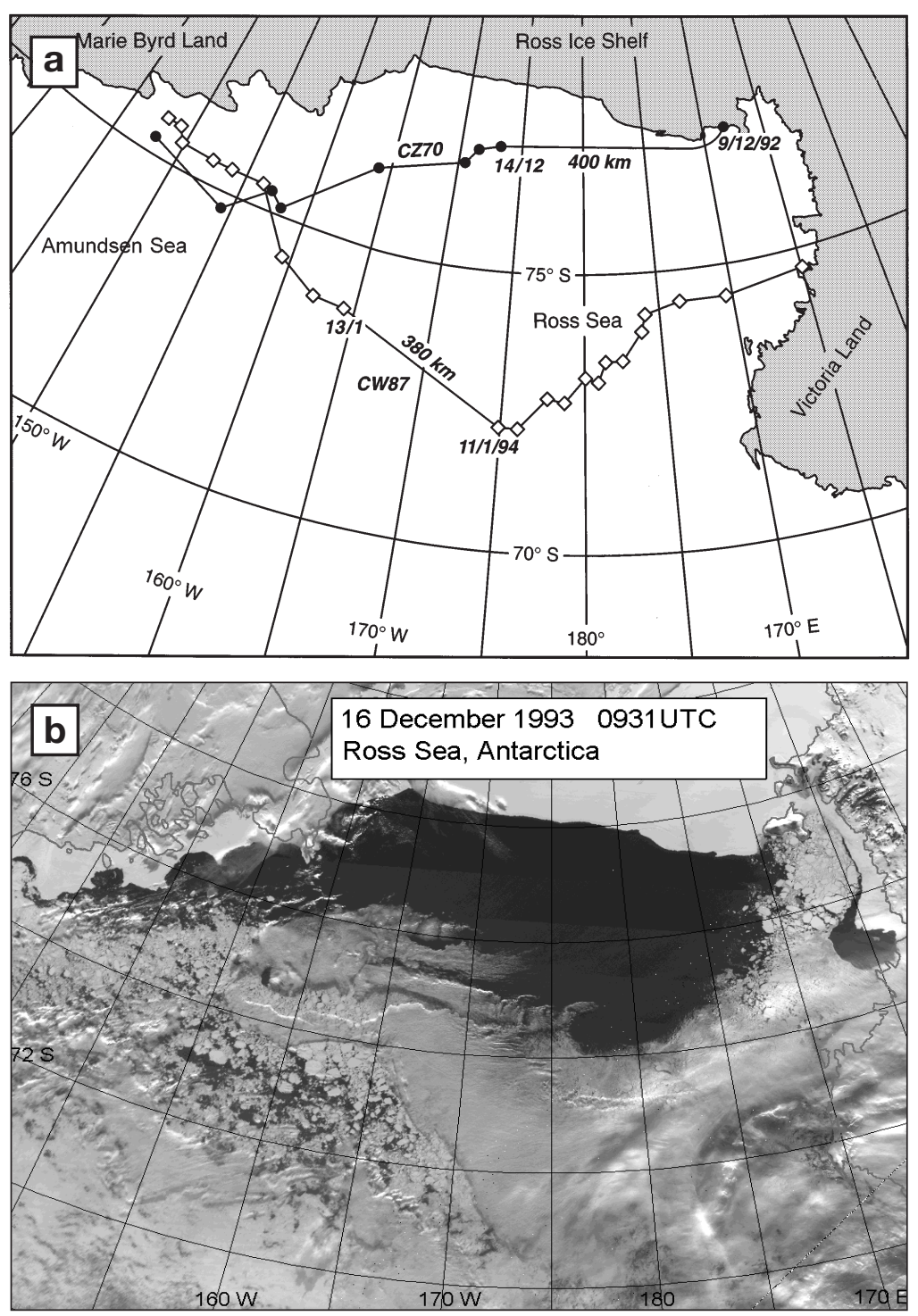

Fig. 1. (a) CZ70: direct track of Cape Crozier bird from 9 December 1992 to 5 January 1993; during the 5 d gap between departure from Cape Crozier and first location, bird traveled at average daily rate of at least $80 \mathrm{~km} \mathrm{~d}^{-1}$. CW87: indirect track of a Cape Washington bird from 22 December 1993 to 30 January 1994; bird traveled rapidly to western edge of pack-ice and then slowly across pack-ice to and along the eastern edge until 11 January, at which time there were no locations for $2 \mathrm{~d}$ and bird traveled at least $380 \mathrm{~km}$ to next location on 13 January. (b) Satellite image of Ross and Amundsen Sea; image obtained from NOAA-9 and processed by Antarctic Research Center (AARC), Scripps Institution of Oceanography. Clouds obscure some of sea surface, but much of pack-ice can be seen and the distribution is common for this time of year. Note broad area of open water in Ross Sea. Image is not to same scale as (a) 
colony to the moult site was $1245 \mathrm{~km}$. The daily average distance taken from a single Class 1 location each $24 \mathrm{~h}$ was $47.1 \mathrm{~km}$. This does not account for any deviations from a direct track over the course of the $24 \mathrm{~h}$. After arrival, the daily travel rate dropped to $7.1 \mathrm{~km}$ (Table 1).

\section{Tracks and moult locations in the Ross Sea}

Moult tracks for 8 birds were obtained; 4 of these were direct routes and 3 were indirect. The most direct route appears to be from CZ70, a bird en route from Cape Crozier. There was an $8 \mathrm{~d}$ gap after departure from the colony, and it is assumed that during that period it was in the water most of the time while traveling direct to the next location $400 \mathrm{~km}$ from the colony (Fig. 1). Other direct routes not illustrated were: (1) the course of CW70, which was probably direct because daily travel rate was one of the fastest measured; from 22 December, when it was at Cape Washington, until 5 January when it was $1160 \mathrm{~km}$ to the east in the Amundsen Sea, no locations were obtained; after that date, several locations were obtained as the bird continued to travel east for about $12 \mathrm{~d}$ when it swam or drifted west until the last fix on 14 February. (2) The direct route for CW66 shows an arc to the north of nearly $2^{\circ}$ as the bird traveled from Cape Washington to the eastern Ross Sea. (3) A similar northern arc was traveled by CW88 and, less so, by CW82, as these birds traveled from Cape Washington.
An indirect route to the moult area was taken by CW87 (Fig. 1a). The arc of this bird was similar to that of the other CW birds, but more exaggerated, to the extent that the bird reached a northerly latitude of almost $72^{\circ} \mathrm{S}$. Curiously, the bird traveled rather slowly until 11 January, then in the next $2 \mathrm{~d}$ it traveled $380 \mathrm{~km}$, after which its speed returned to about that of the previous $2 \mathrm{wk}$. Two other indirect routes were of birds that, after release in late October from Cape Roget, never returned to the colony. As non-breeders or unsuccessful breeders it is not surprising that they might wander extensively. What is of special interest, however, is that they made their way from a latitude above $70^{\circ} \mathrm{S}$, which is beyond the Ross Sea, back into the Ross Sea and to the moult area of the breeding birds (Fig. 2). There was one outlier that did not travel from the western Ross Sea colonies to Ross/Amundsen Sea area. This bird, CI91, went north of Cape Roget (Fig. 2).

From various satellite images collected and reviewed over the course of the study, it can be seen that in order to reach the moult area the birds journeying from the colonies of the western Ross Sea had to cross a band of pack-ice extending from near the coast to about the 172nd meridian. Beyond this pack-ice there was light pack or open water to about $175^{\circ} \mathrm{W}$. The boundary of the eastern pack-ice edge extended south to nearly $76^{\circ} \mathrm{S}$, just north of Cape Colbeck. This region shows extensive, heavy pack-ice, with some large floes, similar to the pattern observed for many previous years (Gloersen et al. 1992).

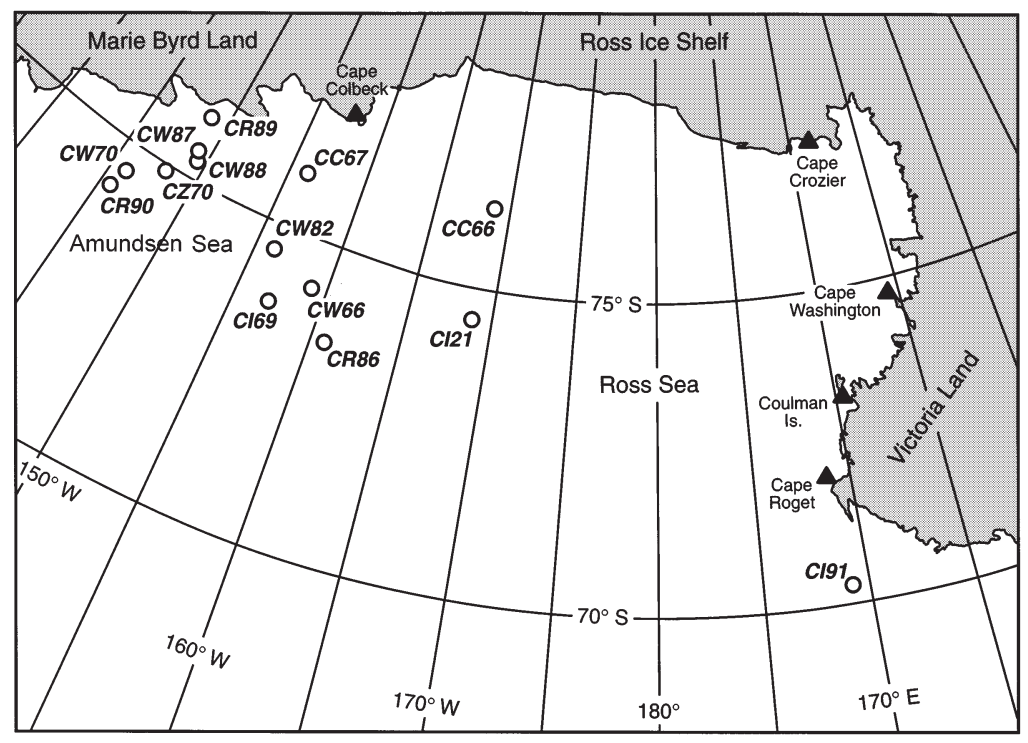

Fig. 2. Aptenodytes forsteri. Location of colonies where birds were released with attached satellite transmitters $(\mathbf{\Lambda})$, and moult location of birds tracked from these colonies (O). Code names for birds match those in Table 1

\section{Moult locations in the Weddell Sea}

Location of moulting birds in the Weddell Sea may be atypical because of the unusual ice-free conditions in 1998. The ship's track and location of bird sightings are shown in Fig. 3, the more normal ice-pack distribution in Fig. $4 \mathrm{a}$, and moult sites in Table 2. Birds were sighted in the western Weddell Sea, near the base of the Antarctic Peninsula, at about $55^{\circ} \mathrm{W}$ and $72^{\circ} \mathrm{S}$. At this (late January) time there was a concentration of packice in the west central part of the Weddell Sea, but extensive open water along the Ronne and Filchner Ice Shelf. The birds were present on the southern edge of an extensive pack-ice region. This ice distribution contrasts with more normal years when pack-ice extends south to the ice shelves (Gloersen et al. 1992). 


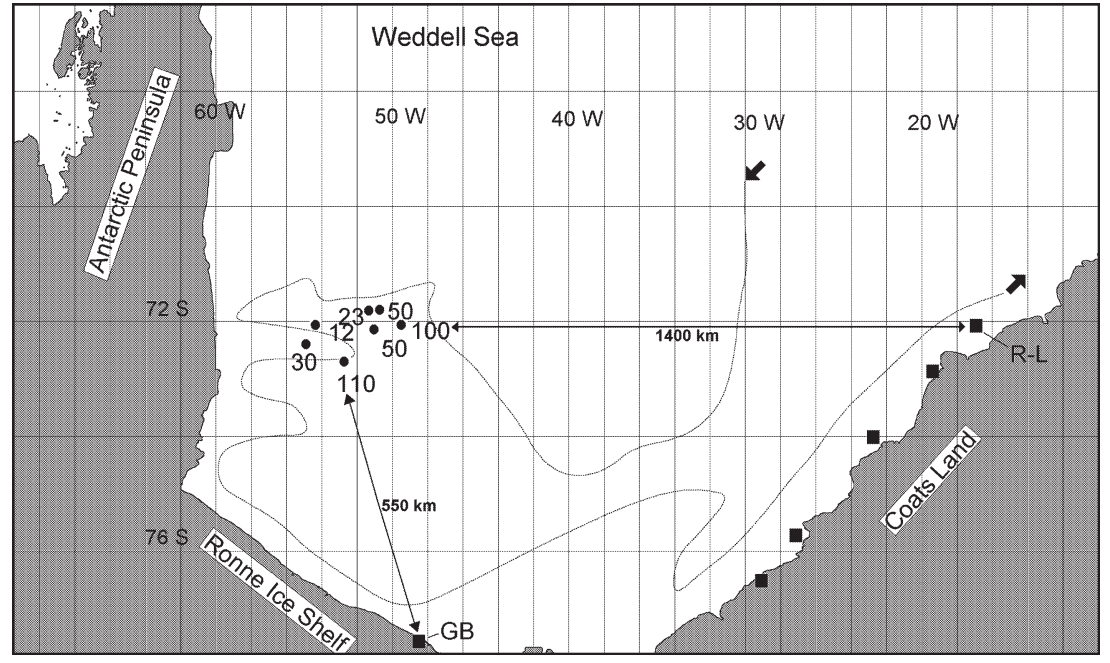

Fig. 3. Track of HMS 'Endurance' (dotted curve), location of largest groups of Aptenodytes forsteri $(\bullet)$, and location of nearest known emperor penguin colonies $(\boldsymbol{\bullet})$. Numbers next to circles $=$ size of group. Nearest colony of Gould Bay (GB) is $550 \mathrm{~km}$ from the site, and most distant is Riiser-Larson (R-L) at $1400 \mathrm{~km}$ ing $30 \mathrm{~d}$, they should search for concentrated pack-ice with large floes. These are traditional packice areas that annual satellite images show are present in about the same place and dimensions every year (Gloersen et al. 1992). Based on the diaries of the early explorers, this ice distribution has been consistent for at least $100 \mathrm{yr}$.

Near the turn of the century, when Scott and his party were exploring the face and boundaries of the Ross Ice Shelf in January 1902, they noted a large concentration of emperor penguins near the Prince Edward VII Peninsula (Wilson 1907). Wilson assumed that the origin of the birds was near the peninsula and speculated that there must be a very large colony in the area. Later, during cruises from mid-December to late February in the years 1976 to 1980, a US expedition in the same area counted emperor penguins and calculated the density and total population of birds (Ainley et al. 1984). Based on the

\section{Moult location}

Why does Aptenodytes forsteri travel so fast and far to moult? The answer is at least 3-fold: (1) during the moult, when the birds renew all of their feathers at one time, they are unable to swim efficiently and are unable to enter the water without serious thermoregulation problems (Erasmus et al. 1981); (2) vigorous activity of the blood-engorged wings may cause them to bruise and bleed easily; (3) they lose their hydrodynamic streamlining because of the ragged surface created by the moulting feathers (Wilson 1985). At the time of year when they moult, the sea-ice is melting and breaking up. This is especially so in the western Ross Sea, where the colony sites become open water in the process of ice retreat. The only reliable and large body of pack-ice is at the border of the Ross and Amundsen Seas over $1000 \mathrm{~km}$ away (Fig. 1b; see also Gloersen et al. 1992). This pack-ice extends to the base of the Antarctic Peninsula, and is second in size only to the summer pack-ice refugia of the Weddell Sea. Because the birds must select floes that will last for the follow-
Table 2. Weddell Sea moult-site characteristics, January 1998; south latitude and west longitude. Floes with no birds had guano stains and penguin feathers.

Floe size $=$ characteristic floe diameter in area around observation site

\begin{tabular}{|c|c|c|c|c|c|}
\hline $\begin{array}{l}\text { Date } \\
\text { Lat., Long. }\end{array}$ & Area & No. of penguins & $\begin{array}{l}\text { Floe size } \\
\text { (m) }\end{array}$ & $\begin{array}{c}\text { Ridged } \\
(\%)\end{array}$ & $\begin{array}{c}\text { Ice cover } \\
(\%)\end{array}$ \\
\hline \multicolumn{6}{|l|}{27 Jan } \\
\hline $72.3,55.1$ & 1 & 0 & 20 & Yes & \\
\hline \multicolumn{6}{|l|}{28 Jan } \\
\hline $71.6,56.7$ & 1 & 1 & 100 & 50 & 9 \\
\hline $71.6,56.6$ & 1 & 0 & 100 & 50 & 9 \\
\hline $71.6,56.4$ & 1 & 0 & 100 & Yes & 6 \\
\hline $71.5,56.3$ & 1 & 0 & 200 & No & 6 \\
\hline $71.5,56.2$ & 1 & 0 & 100 & Yes & 6 \\
\hline $71.4,56.0$ & 1 & $7-8$ & 100 & $\mathrm{Yes}^{\mathrm{a}}$ & 9 \\
\hline $71.4,55.8$ & 2 & 0 & 500 & No & 9 \\
\hline $71.4,55.8$ & 1 & 0 & 100 & No & 9 \\
\hline $71.3,55.6$ & 1 & $5-6$ & 700 & 10 & 9 \\
\hline $71.4,54.5$ & 1 & 0 & $20-100$ & No & 9 \\
\hline $71.6,56.8$ & $3^{b}$ & 0 & $20-100$ & Yes & 3 \\
\hline $71.6,56.5$ & 1 & 7 & $20-100$ & Yes & 8 \\
\hline \multicolumn{6}{|l|}{$30 \mathrm{Jan}$} \\
\hline $72.1,54.7$ & $2^{b}$ & 12 & $500-2000$ & Yes & 5 \\
\hline $72.1,54.7$ & 1 & 8 & $500-2000$ & Yes & 5 \\
\hline $72.2,54.8$ & 1 & 0 & $<20$ & Yes & 5 \\
\hline $72.4,55.1$ & 2 & 30 & $500-2000$ & Yes & 3 \\
\hline \multicolumn{6}{|c|}{$\begin{array}{l}{ }^{\text {a }} \text { This floe featured } 2 \text { parallel ridges with a heavy coating of feathers and } \\
\text { guano between them } \\
\text { bEach moult area was on an individual floe }\end{array}$} \\
\hline
\end{tabular}


concentration of birds sighted, Ainley et al. (1984) estimated that there were probably 100000 emperors in the area and that a putative colony of birds near Cape Colbeck might have as many as 70000 breeding birds. On a later cruise, from mid-February to early April
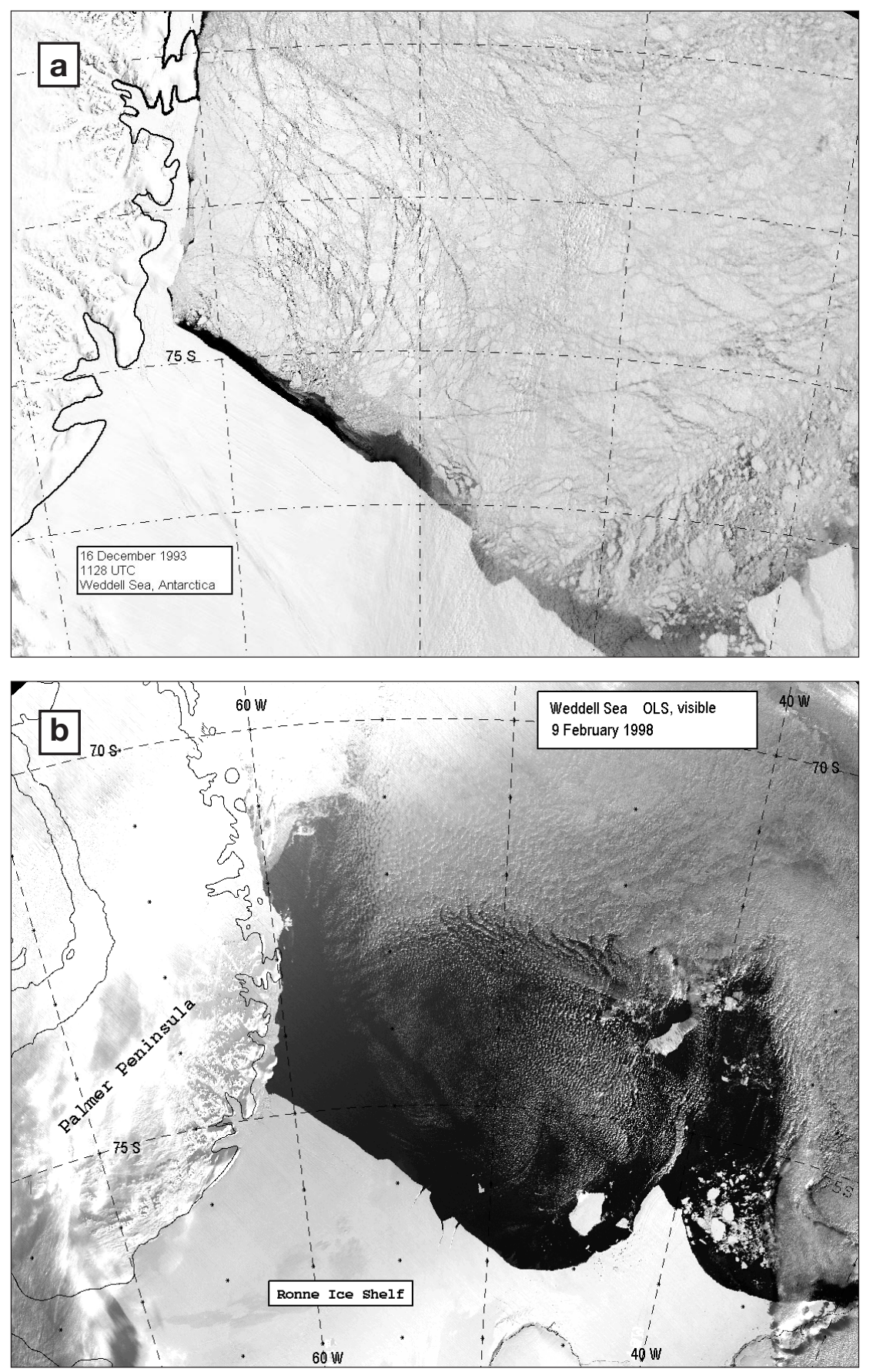

Fig. 4. (a) Satellite image of Weddell Sea in December 1993. Image processed by AARC. Pack-ice distribution in this year is characteristic of most years. Image is 1 degree south of where penguins were found. (b) Satellite image of Weddell Sea in February 1998. Image processed by AARC from defense meteorological-satellite program (DMSP). Visible spectrum and $0.6 \mathrm{~km}$ resolution. Note much reduced pack-ice
1994, Ainley once again noted in mid-February a concentration of birds from about 50 to $200 \mathrm{~km}$ north and northwest offshore of King Edward VII Peninsula (unpubl. obs.). These groups ranged in size from 1 to 25 birds. At this late date the birds had most probably finished moult, and this is corroborated by the observation that many were in the water. From this region across the rest of the Amundsen and Bellingshausen Seas to the base of the Antarctic Peninsula few emperor penguins were seen. Unknown to Wilson (1907) and Ainley et al. (1984) was the fact that the source-colony for many of these birds was probably located in the western Ross Sea. It is noteworthy that Ainley et al.'s estimate of the total number of birds in the area is close to what we estimate to be the number crossing from the western Ross Sea colonies.

We propose that the consistency of the tracks, rate of travel, and arrival in the eastern Ross Sea near Cape Colbeck of the 11 of 12 successfully satellite-tagged birds is reasonable confirmation that the preferred moult area for most of the approximately 100000 breeding Ross Sea birds is in this region. Only one of these birds, CI91, went elsewhere. Curiously, locations from this bird's transmitter ended in early January. No further receptions may have been because of transmitter battery depletion, shedding of the transmitter on thin ice and subsequent sinking, or the demise of the bird because of predation.

The average departure date of parenting birds is 20 December, which nearly coincides with the peak time of departure of juveniles from the colony (Kooyman et al. 1990). It would seem that the parents continue to return to the colony as long as they can find their chick, or when it gets too close to the time that their moult will begin. Some anticipation of this event is necessary for them to have time to travel over $1000 \mathrm{~km}$ 
to the moult area in the eastern Ross Sea. The average of $47 \mathrm{~km} \mathrm{~d}^{-1}$ still requires $3 \mathrm{wk}$ for them to reach the area, and presumably this includes feeding and fattening on the way. If the parents make a poor decision and delay the departure too long, then they risk not reaching a suitable moult area before the moult begins, and also not having fattened enough to be in good condition towards the end of the moult. It would seem that the longer the birds continue to return to the colony and feed their chick, the more likely this gamble and investment will pay off in the chick succeeding in its departure from the colony in good condition.

Is the period from pre-moult feeding and fattening to the post-moult feeding before breeding the time of highest mortality in adult emperor penguins? We suggest that it is for the following reasons: (1) At the time of departure from the colony and abandonment of the chicks the average weight of birds is $\sim 24 \mathrm{~kg}$ (Table 1 ). About $23 \mathrm{~kg}$ is the minimum body mass required before the birds advance into Phase III fasting, which involves the depletion of body proteins and the highest rates of body-mass loss (Le Maho et al. 1976). To ensure that they remain above this critical body mass, the birds must gain $\sim 15$ to $20 \mathrm{~kg}$ from the time of colony departure until they begin the fast $1200 \mathrm{~km}$ to the east. If the average daily mass loss is $587 \mathrm{~g} \mathrm{~d}^{-1}$, which is based on a body-mass decline of captive moulting birds of 488 to $691 \mathrm{~g} \mathrm{~d}^{-1}$ (Adams \& Brown 1990), then the mass loss during 1 mo of moulting is high compared to the long breeding and incubation fast. Despite the low temperatures, the metabolic rate of males incubating eggs is at an exceptionally low level of $25 \%$ below resting, and mass loss averages $137 \mathrm{~g} \mathrm{~d}^{-1}$ (Ancel et al. 1997). (2) While the moult is in progress, sea-ice coverage continues to decline, and if the floe selected deteriorates extensively it may become unsuitable as a moulting platform. The bird may have the untenable option of attempting to swim to another floe under circumstances when the feathers will not provide adequate insulation. (3) Diminished size of the ice floes may enable leopard seals or killer whales to search, find more easily, and capture birds on the ice. (4) After the moult, some birds may be in poor physical condition because of the substantial weight loss. If food is not readily available, they may ultimately starve to death as body condition continues to decline while they are in search of prey. It is significant that the highest adult mortality in Adelie penguins of $\sim 25 \%$ occurs between the end of the breeding season and the resumption of breeding the following spring (Davis et al. 1996). This result should be treated with caution, however, because all the birds were banded, and it has been observed that mortality in this species associated with the first year of banding is at least $28 \%$ (Ainley et al. 1983).

\section{Sea-ice conditions}

Adelie penguins are the only other species of penguin that generally moults on sea-ice. One important advantage Adelie penguins have over emperor penguins is that their moult begins in early March, when fall temperatures have declined to freezing levels and the seaice has begun to expand. The floes that Adelie penguins are likely to select for their moult are most likely to increase in size and thickness rather than to decrease.

Direct observations of the area where emperor penguins moult are rare because these regions are so remote. The area within the Ross and Amundsen Seas is exceptional because emperor penguin distribution has been recorded several times as ships have traversed the area on different research expeditions. Most recently the RV 'Nathaniel B. Palmer' passed through during the summer of 1998/1999 to study pack-ice. In a very brief summary of some of the observations in early January and February at the latitudes of $\sim 75$ to $78^{\circ} \mathrm{S}$ and 150 to $166^{\circ} \mathrm{W}$ they noted: (1) an air temperature range of -0.5 to -11.1 ; (2) wind of calm to $13.9 \mathrm{~m} \mathrm{~s}^{-1}$; (3) cloud cover of $100 \%$ stratus to clear; (4) ice thickness of new ice of 15 to $30 \mathrm{~cm}$ to thicker old ice in the Bay of Whales. One of the days when large numbers of penguins were sighted was 31 January at $74^{\circ} \mathrm{S}$ and $140^{\circ} \mathrm{W}$. Numerous birds were seen in various stages of moult on pack-ice, where the coverage was $90 \%$; most of this was 30 to $60 \mathrm{~cm}$ thick, with a snow cover of 20 to $30 \mathrm{~cm}$. The sky was completely overcast, the wind was $6.2 \mathrm{~m} \mathrm{~s}^{-1}$, and the temperature ranged from -1.1 to -3.2 . The most exceptional day was in Sulzberger Bay $\left(\sim 77^{\circ} \mathrm{S}, 150^{\circ} \mathrm{W}\right)$, on which the birds were too numerous for the ship's mate to count while in transit (M. Watson pers. comm.).

For the first time, emperor penguins were seen moulting in the Weddell Sea during January and February of 1998 by 2 of us (S.F.A, E.C.H). The birds were generally in small groups of 5 to 20 on pack-ice of about $90 \%$ coverage. The floes were at least $100 \mathrm{~m}^{2}$, and some larger floes $\left(\geq 500 \mathrm{~m}^{2}\right)$ carried 2 or more groups of penguins, separated by several hundred meters. Many moulting sites did not have birds present, and appeared to have been used by only a few birds. Moult areas (Table 2) were seen on floes as small as $20 \mathrm{~m}^{2}$, and were located close to the southern edge of the pack-ice massif in the western Weddell Sea. It is notable that neither birds nor moult sites were observed further north, where floes are vast $(>2 \mathrm{~km})$ and the pack is nearly unbroken. In areas with moult sites, both level and ridged ice-floe types were present; the distinguishing characteristic of the floes that contained moult areas was ridged ice: in a field of both level and ridged floes, the birds invariably chose the ridged floes. Ridges provide protection from the wind, and 
these floes are slower to disintegrate than level ice, providing a more stable platform for the moult.

The year 1998 was one of unusually little pack-ice, which allowed the research vessel to penetrate further into the western Weddell Sea than ever before (Fig. 4). Moult areas for the Weddell Sea colonies may be further south and east in normal years. This would reduce the distance necessary for birds to travel from some of the colonies in this region. The present location shows that the birds had to travel from 550 to $1400 \mathrm{~km}$ (Fig. 5). The most distant colony from the Weddell Sea moult area would be Atka Bay $1400 \mathrm{~km}$ to the east. There may also be undiscovered colonies in the eastern Weddell Sea that utilize this area as well. For example, juveniles were seen in numbers on ice floes near Snow Hill Island $\left(64.5^{\circ} \mathrm{S}, 57.2^{\circ} \mathrm{W}\right)$ near the northern limit of the Antarctic Peninsula (J. Chester pers. comm.). The coats of these juveniles were still covered by $60 \%$ down. We have noted at Cape Washington that once birds with down enter the water, it matts and is rapidly lost. This indicates to us that juveniles must have come from a nearby colony.

With the exception of a group of 25 emperor penguins seen by Ainley (unpubl. obs.) in pack-ice, the birds were dispersed. In contrast, those seen by Robertson (pers. obs.) on solid fast-ice were congregated in large numbers. A similar observation was made by Wilson (1907), who claimed to have seen hundreds of birds in a bay near Edward VII Peninsula. Other important factors in the size of aggregations may be related to the risk of predation, and also guano contamination of the ice. Large numbers of birds are more easily detected and more attractive to predators than single individuals on ice floes. In addition, the guano deposit from a large number of birds on floes could contribute significantly to the deterioration of the ice. This would be less of a problem on a large plate of fast-ice such as observed by Wilson (1907) and by Robertson (pers. obs.). Finally, based on the observations of this report and the known late-season pack-ice regions indicated by satellite imagery (Gloersen et al. 1992, Nicol \& Allison 1997), we propose that other moulting areas around the continent can be predicted. Fig. 5 indicates where other reliable pack-ice areas in January and February are found, and their distances from known colonies.
Acknowledgements. There are many who assisted in crucial ways during this project. A few of those of especial prominence were the staff of the NSF that managed the operational details, the Antarctic Support Associates (ASA) field- and airsupport staff, the twin-otter pilots H. Perk and H. Hanlon of K. Borek Ltd, and especially the field assistance of C. Kooyman, T. Kooyman, and M. Horning. Satellite images for analysis of ice distribution were provided by R. Whritner and B. Nelson, of AARC at Scripps Institution of Oceanography, and A. Archer of ASA. ASA, under contract (OPP89-22832) to the Office of Polar Programs, National Science Foundation provided the meteorological and sea-ice data in daily situation reports sent from the RV 'Nathaniel B. Palmer' on Cruise NBP 99-1 in the Ross Sea. Financial support was provided by NSF OPP Grants NSF DPP 87-15864, NSF OPP 92-19872; NSF OPP 96-15390 to G.L.K.

\section{LITERATURE CITED}

Adams NJ, Brown CR (1990) Energetics of molt in penguins. In: Davis LS, Darby JT (eds) Penguin biology. Academic Press Inc, San Diego, p 297-315

Ainley DG, LeResche RE, Sladen WJL (1983) Breeding biology of the Adelie penguin. University of California Press, Berkeley

Ainley DG, O'Connor EF, Boekelheide RJ (1984) The marine ecology of birds in the Ross Sea, Antarctica. Ornithological Monograph No. 32, Am Ornithol Union, p 17-91

Ancel A, Visser H, Handrich Y, Dirkjan M, Le Maho Y (1997) Energy saving in huddling penguins. Nature 385:304-305

Davis LS, Boersma PD, Court GS (1996) Satellite telemetry of the winter migration of Adelie penguins (Pygoscelis adeliae). Polar Biol 16:221-225

Erasmus T, Randall RM, Randall BM (1981) Oil pollution, in-

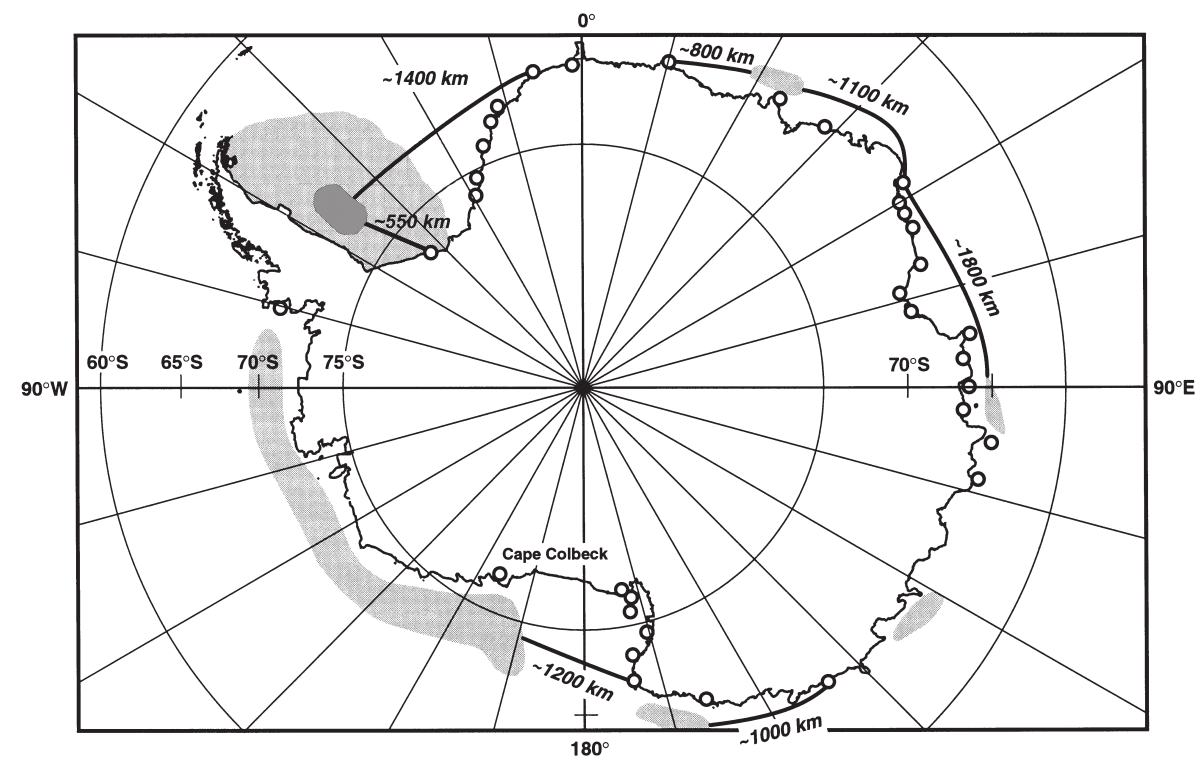

Fig. 5. Aptenodytes forsteri. General sketch of known colonies of emperor penguins, general distribution of late summer pack-ice (shaded areas), and distances of selected colonies to edge of these pack-ice areas. Data adapted from February pack-ice distribution of Gloersen et al. 1992). Internal hatched area covers region that moulting birds were sighted in 1998 (see last paragraph of 'Results') 
sulation and body temperatures in the jackass penguin Spheniscus demersus. Comp Biochem Physiol 69A:169-171

Gloersen P, Campbell WJ, Cavalieri DJ, Comiso JC, Parkinson CL, Zwally HJ (1992) Arctic and antarctic sea-ice, 1978-1987: satellite passive-microwave observations and analysis. Vol NASA SP-511. National Aeronautics and Space Administration, Washington, DC

Kooyman G, Gentry R, Bergman W, Hammel H (1976) Heat loss in penguins during immersion and compression. Comp Biochem Physiol 54A:75-80

Kooyman GL, Croll D, Stone S, Smith S (1990) Emperor penguin colony at Cape Washington, Antarctica. Polar Rec 26: 103-108

Le Maho Y, Delclitte P, Chatonnet J (1976) Thermoregulation

Editorial responsibility: Otto Kinne (Editor),

Oldendorf/Luhe, Germany in fasting emperor penguins under natural conditions. Am J Physiol 231:913-922

Nicol S, Allison I (1997) The frozen skin of the Southern Ocean. Am Sci 85:426-439

Voitkevich AA (1966) The feathers and plumage of birds, 1st edn. October House Inc, New York

Welty JC (1975) The life of birds, 2nd edn. WB Saunders Company, London

Wilson EA (1907) II. Aves. Aptenodytes forsteri, the emperor penguin. In: Natural History, Vol II. Zoology (Vertebrata: Mollusca: Crustacea). National Antarctic Expedition 1901-1904. British Museum, London, p 1-31

Wilson RP (1985) The jackass penguin (Spheniscus demersus) as a pelagic predator. Mar Ecol Prog Ser 25:219-227

Submitted: July 5, 1999; Accepted: January 7, 2000

Proofs received from author(s): September 4, 2000 